\title{
Omental Infarction: a Reappraisal of Conservative Management in Children
}

\author{
Enfarte do Omento: Avaliação do Tratamento Conservador em Idade Pediátrica
}

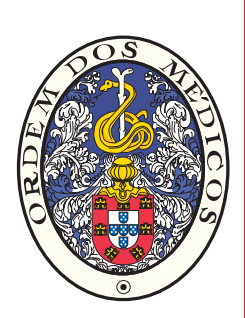

José ESTEVÃO-COSTA ${ }^{1}$, Ana Sofia ALVARENGA ${ }^{1}$, Ana Catarina FRAGOSO ${ }^{1}$, Maria GARCIA ${ }^{1}$, Miguel CAMPOS ${ }^{1}$

Acta Med Port 2014 Jul-Aug;27(4):433-436

ABSTRACT

Introduction: Accurate recognition of omental infarction has resulted in increasing supporters of non-operative approach. In order to assess the efficacy and safety of conservative management, we surveyed the cases of omental infarction treated at a single institution. Material and Methods: Primary omental infarction treated between 2004 and 2011 were reviewed. Cases recognized by imaging studies were submitted to conservative treatment that consisted of intravenous analgesics and antibiotics. Demographics, clinical presentation, laboratory findings, imaging diagnosis and outcome were analyzed.

Results: There were 9 cases of omental infarction. Eight patients (4 males; median age, 8.5 years) presented at initial course of disease; all had right-sided abdominal pain and a normal or lightly increased leukocyte count. Six cases, diagnosed by CT scan after US suspicion in four, were managed conservatively, recovered uneventfully, and were discharged after a median hospital stay of 3 days. Two patients were only recognized at surgery. An additional case presented with intestinal obstruction due to an internal hernia and was successfully resolved by laparoscopy.

Discussion: Imaging techniques were diagnostic of omental infarction in the majority of cases, enabling a conservative approach to be adopted. Non-operative management was successful with no complications in all patients presenting at the initial course of disease. One patient presented with a harmful complication that required operative treatment.

Conclusion: In the absence of a standard approach for omental infarction, conservative management is an effective noninvasive alternative but it claims for active surveillance.

Keywords: Infarction; Omentum.

\section{RESUMO}

Introdução: A melhoria da acuidade diagnóstica do enfarte do omento resultou num incremento da atitude conservadora no seu tratamento. Com o objectivo de avaliar a eficácia e segurança da abordagem não-operatória, analisámos os casos de enfarte do omento tratados num hospital terciário.

Material e Métodos: Incluímos os casos de enfarte do omento primários tratados entre 2004 e 2011. Os enfartes do omento diagnosticados por imagiologia foram submetidos a tratamento conservador que constou de analgésicos e antibioterapia intravenosa. Avaliámos os dados demográficos, apresentação clínica, dados laboratoriais, imagiologia e resultado.

Resultados: Ocorreram nove casos de enfarte do omento. Oito pacientes (4 rapazes), com uma idade mediana de 8,5 anos, apresentaram-se na fase inicial da doença por dor abdominal à direita; a contagem leucocitária era normal ou ligeiramente elevada. Seis casos, diagnosticados por TC após ecografia suspeita de enfarte do omento em quatro, foram trados conservadoramente sem complicações, tendo alta ao terceiro dia (mediana). Dois doentes foram apenas diagnosticados durante a intervenção cirúrgica por suposta apendicite. O nono caso apresentou-se com uma obstrução intestinal devida a hérnia interna que foi resolvida por laparoscopia.

Discussão: A imagiologia foi diagnóstica na maioria dos casos de enfarte do omento, permitindo a adoção de uma abordagem conservadora. O tratamento não-operatório foi eficaz e sem complicações em todos os doentes que se apresentaram na fase inicial da doença. Um doente apresentou-se com uma complicação grave que requereu intervenção cirúrgica.

Conclusão: $\mathrm{Na}$ ausência de um tratamento consensual para o enfarte do omento, a abordagem não-operatória é uma alternativa não invasiva e eficaz, mas requer uma vigilância clínica ativa.

Palavras-chave: Enfarte; Omento.

\section{INTRODUCTION}

Primary omental infarction $(\mathrm{OI})$ is a rare condition in children that, until recently, had been usually diagnosed during surgery for presumed appendicitis. ${ }^{1,2}$ Accurate recognition by imaging techniques coupled with the benign course has resulted in increasing supporters, including us, of non-operative management. ${ }^{3-8}$ We surveyed our series of Ol cases focusing on the outcome of conservative management.

\section{MATERIAL AND METHODS}

The cases of primary OI treated at a single institution

from September 2004 to August 2011 were reviewed. All patients underwent abdominal US evaluation; CT scan was considered necessary to confirm the diagnosis. Patients diagnosed by imaging techniques were assigned to conservative treatment; the latter consisted of intravenous analgesics and antibiotics in a hospital setting. Discharge occurred when patients were asymptomatic or required only oral analgesics.

Demographics, clinical presentation, imaging diagnosis and outcome were analyzed. Data is expressed as median followed by the range in square brackets.

\footnotetext{
1. Serviço de Cirurgia Pediátrica. Centro Hospitalar S. João. Faculdade de Medicina. Universidade do Porto. Porto. Portugal.
}

Recebido: 16 de Novembro de 2013 - Aceite: 18 de Março de 2014 | Copyright @ Ordem dos Médicos 2014 


\section{RESULTS}

There were nine cases of $\mathrm{Ol}$, which corresponded approximately to $0.4 \%$ of all appendectomies $(n=2015)$ performed in the same time span.

Eight patients (4 males) with an age of 8.5 [6-13] years were treated at initial course of the disease (Table 1). All presented with right-sided abdominal pain accompanied by hyperthermia in two cases; their weight was positioned in percentile 90 [25-95]. Blood tests revealed a white blood cells (WBC) count of 10.49 [7.81-13.08] $\times 10^{\wedge} 9$ and a C-reactive protein (C-RP) of 9.7 [0.6-50.7] mg/L. Abdominal ultrasonography (US) was suspicious of $\mathrm{OI}$ in four patients who underwent computerized tomography (CT) scan that confirmed the diagnosis (Fig. 1); two were diagnosed by CT scan after a negative US. These six patients were submitted to conservative treatment and discharged after $3[2-8]$ days of hospital stay. Two cases were only recognized at surgery after an US presumptive of acute appendicitis. All the patients recovered uneventfully and at a follow-up of 61 [1697] months none experienced recurrence or complications. The ninth case, previously reported,$^{9}$ was a 13 -year-old boy that presented with an internal hernia secondary to adhesions due to a segmental unrecognized $\mathrm{OI}$, and was successfully resolved by laparoscopic approach.

\section{DISCUSSION}

Omental infarction (OI) is an uncommon cause of acute abdominal pain in children; because it has been usually misdiagnosed as acute appendicitis, its prevalence is often expressed as a proportion of the children that underwent appendectomy, e.g. approximately $0.1 \% .{ }^{10}$ The higher ratio (1:224) found in our series is in accordance with more recent reviews; ${ }^{11,12}$ this may reflect the increasing disease's recognition and/or incidence, the latter being related to the growing prevalence of childhood obesity, a predisposing risk factor in Ol.7,8,13

$\mathrm{OI}$ is no longer a surprisingly intra-operative finding. Although not decisive, clinical awareness is important for the diagnosis. A clinical picture of 'atypical appendicitis' in a well-being obese child should lead to consider this diagnosis; a palpable mass in the right quadrant strongly suggests $\mathrm{Ol}$ but it is an infrequent finding. 2,6,11,13,14 Laboratory exams are unremarkable; as we found, WBC count and C-RP are usually within normal range or lightly elevated. The widespread availability and use of high-quality imaging techniques in the setting of acute abdominal pain has been the main reason for increasing and confident diagnosis. The diagnosis of $\mathrm{Ol}$ is in fact based on cross-sectional imaging. ${ }^{6,8,15}$ Abdominal US may raise the suspicion by revealing a hyperechoic mass, but as occurred in our series it has low sensitivity. ${ }^{4,16}$ CT is the gold standard and shows a large, cake-like, high-attenuation fatty mass centered in the omentum; ${ }^{3-5,17}$ additionally it may be essential to unequivocal exclusion of appendicitis.

Accurate diagnosis of $\mathrm{Ol}$ coupled with the self-limited course of the disease has led some authors to recommend conservative care. ${ }^{3-5,7,18}$ Inherent anesthetic risk and aesthetic repercussion related to operative treatment are the most important considerations supporting the conservative management, despite the latter are less relevant when laparoscopy is used.

The best management of $\mathrm{Ol}$ is however controversial, with many surgeons favoring the operative treatment. ${ }^{1,11,15,19}$ The main issues under debate are related to length of recovery and potential complications. Conservative management is usually associated with longer hospitalization because of the severity of pain; this is particularly verifiable for the comparison with the prompt recovery after operative treatment by laparoscopic approach. ${ }^{1,12,15,19}$ Besides the questionable impact of the reported difference between

Table 1- Clinical cases

\begin{tabular}{|c|c|c|c|c|c|c|c|c|c|}
\hline Case & Age/Sex & Weight (P) & Fever & WBC & C-RP & US & CT & Approach & Hospital stay (d) \\
\hline 1 & $12 y / M$ & $\mathrm{P} 25$ & No & 9.81 & 18.2 & + & + & Conservative & 5 \\
\hline 2 & $6 y / F$ & P50 & Yes & 13.08 & 50.7 & - & + & Conservative & 2 \\
\hline 3 & $6 y / F$ & P95 & No & 11.17 & 7.22 & $\mathrm{Aa}$ & $\mathrm{N} / \mathrm{P}$ & Surgery & 3 \\
\hline 4 & $8 y / M$ & P90 & No & 11.48 & 3.4 & + & + & Conservative & 3 \\
\hline 5 & $11 \mathrm{y} / \mathrm{M}$ & P75 & No & 7.8 & 38.7 & + & + & Conservative & 3 \\
\hline 6 & $13 y / F$ & P90 & Yes & 8.29 & 0.6 & - & + & Conservative & 8 \\
\hline 7 & $7 y / M$ & P95 & No & 7.81 & 12.2 & + & + & Conservative & 3 \\
\hline 8 & $9 y / F$ & P90 & No & 11.48 & 6.6 & $\mathrm{Aa}$ & $\mathrm{N} / \mathrm{P}$ & Surgery & 5 \\
\hline
\end{tabular}

P: percentile; WBC: white blood cells count (x10^9); C-RP: c-reactive protein (mg/L); US: ultrasonography; CT: computerized tomography; d: days; y: years; M: male; F: female;

+: suspicious (on US) or diagnostic (on CT scan); -: normal; Aa: acute appendicitis; N/P: not performed 


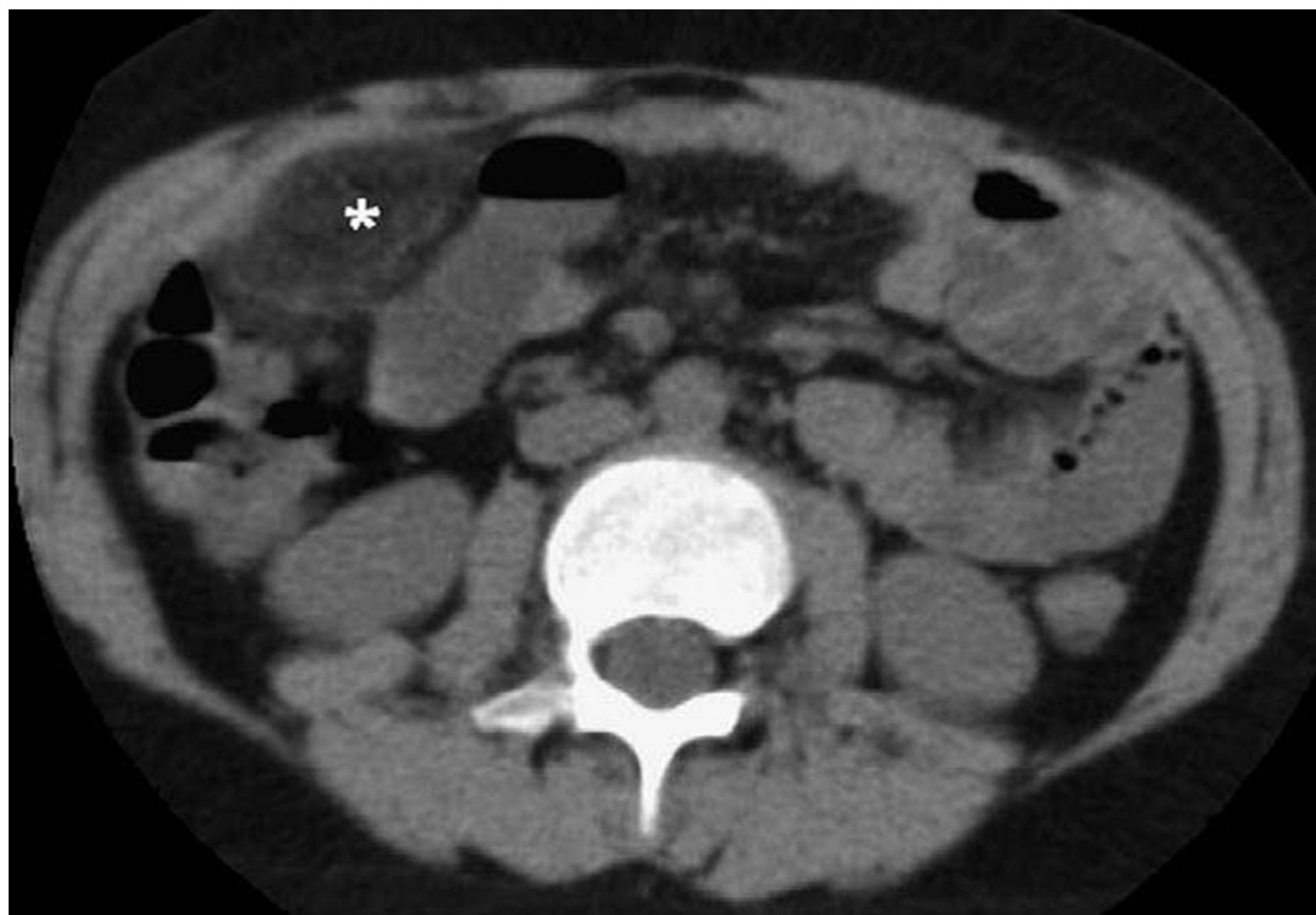

Figure 1 - Computerized tomography scan demonstrating a cake-like, high attenuation, fatty mass (asterisk) confirming the diagnosis of omental infarction

conservative and laparoscopic management (average, 3-4 vs. 2-3 days), ${ }^{11,12,15}$ the length of hospital stay is still an advantage for the supporters of conservative treatment who advocate direct home discharge with analgesics after imaging diagnosis.,

The persistence of necrotic tissue in the abdomen that may result in the development of local abscess and adhesions are hypothetical troubles of conservative management; this may justify prophylactic antibiotics such as a first-generation cephalosporin during in-hospital stay and/or pyrexia. To our knowledge those events have not been previously recorded in children, but are non-negligible complications of surgery although in a much smaller degree in case of laparoscopic approach. As it has been found by others, in our series of patients managed conservatively none experienced complications; ;,18 however, the additional presented case of $\mathrm{OI}$, which mimics conservative management, illustrates the development of a complication (internal hernia) secondary to adhesions.

\section{REFERENCES}

1. Loh MH, Chui CH, Yap T-L, Sundfor A, Tan CEL. Omental infarction - a mimicker of acute appendicitis in children. J Pediatr Surg. 2005;40:12246.

2. Sakellaris G, Stathopoulos E, Kafousi M, Arbiros J, Bitsori M, Charissis G. Primary idiopathic segmental infarction of the greater omentum: two

\section{CONCLUSION}

As recommended by some authors, conservative management may be an appropriate first line treatment, and laparoscopy being indicated when it fails; however, many criteria to proceed with surgery, such as intractable pain, no clinical improvement, persistent peritoneal findings, are not objective evidence-based parameters. ${ }^{12,19}$ In the absence of randomized controlled studies, the pros and cons of conservative versus laparoscopic approach remain elusive with no definitive advantageous one. Our series supports that conservative treatment is a reliable noninvasive alternative for OI management, but it claims for active surveillance.

\section{CONFLICTS OF INTEREST}

The authors declare that there are no conflicts of interest.

\section{FUNDING SOURCES}

No subsidies or grants contributed to this work.

cases of acute abdomen in childhood. J Pediatr Surg. 2004;39:1264-6. 3. Coulier B. Segmental omental infarction in childhood: a typical case diagnosed by CT allowing successful conservative treatment. Pediatr Radiol. 2006;36:141-3

4. Fragoso AC, Pereira JM, Estevão-Costa J. Nonoperative management 
of omental infarction: a case report in a child. J Pediatr Surg. 2006;41:1777-9.

5. Park TU, Oh JH, Chang IT, Lee SJ, Kim SE, Kim CW, et al. Omental infarction: Case series and review of the literature. J Emerg Med. 2012;42:149-54.

6. Puylaert JB. Right-sided segmental infarction of the omentum: clinical, US, and CT findings. Radiology. 1992;185:169-72.

7. Rimon A, Daneman A, Gerstle JT, Ratnapalan S. Omental infarction in children. J Pediatr. 2009;155:427-31.

8. Singh AK, Gervais DA, Lee P, Westra S, Hahn PF, Novelline RA, et al. Omental infarct: CT imaging features. Abdom Imaging. 2006;31:549-54.

9. Estevão-Costa J, Alvarenga A, Garcia M, Campos M. Omental infarction complicated by internal hernia. J Pediatr Surg Case Reports. 2014;2:67.

10. Sweeney MJ, Blestel GA. Primary torsion of the greater omentum. A rare cause of abdominal pain in children. JAMA. 1983;249:3073

11. Helmrath M, Dorfman SR, Minifee PK, Bloss RS, Brandt ML, DeBakey ME. Right lower quadrant pain in children caused by omental infarction. Am J Surg. 2001;182:729-32.

12. Nubi A, McBride W, Stringel G. Primary omental infarct: conservative vs. operative management in the era of ultrasound, computerized tomography, and laparoscopy. J Pediatr Surg. 2009;44:953-6.
13. Varjavandi V, Lessin M, Kooros K, Fusunyan R, McCauley R, Gilchrist B. Omental infarction: risk factors in children. J Pediatr Surg. 2003;38:2335.

14. Georgios M, Evangelia L, Nikolaos B, Evi V, Christopoulos-Geroulanos G: Primary omental torsion in children: ten-year experience. Pediatr Surg Int. 2007;23:879-82.

15. Gosain A, Blakely M, Boulden T, Uffman JK, Seetharamaiah R, Huang $\mathrm{E}$, et al. Omental infarction: Preoperative diagnosis and laparoscopic management in children. J Laparoendosc Adv Surg Tech. 2010;20:77780.

16. Schlesinger AE, Dorfman SR, Braverman RM. Sonographic appearance of omental infarction in children. Pediatr Radiol. 1999;29:598-601.

17. Pereira JM, Sirlin CB, Pinto PS, Jeffrey RB, Stella DL, Casola G. Disproportionate fat stranding: a helpful CT sign in patients with acute abdominal pain. Radiographics. 2004;24:703-15.

18. Aoun N, Nader L, Haddad-Zebouni S, Ghossain M, Akatcherian C. Infarctus segmentaire gauche du grand épiplon chez l'enfant: traitment conservateur. Arch Pediatr. 2006;13:1040-2.

19. Itenberg E, Mariadason J, Khersonsky J, Wallack M. Modern management of omental torsion and omental infarction: A surgeon's perspective. J Surg Educ. 2010;67:44-7. 


\section{Omental Infarction: a Reappraisal of Conservative Management in Children}

Acta Med Port 2014:27:433-436

Publicado pela Acta Médica Portuguesa, a Revista Científica da Ordem dos Médicos

Av. Almirante Gago Coutinho, 151

1749-084 Lisboa, Portugal.

Tel: +351218428215

E-mail: submissao@actamedicaportuguesa.com

www.actamedicaportuguesa.com

ISSN:0870-399X | e-ISSN: 1646-0758

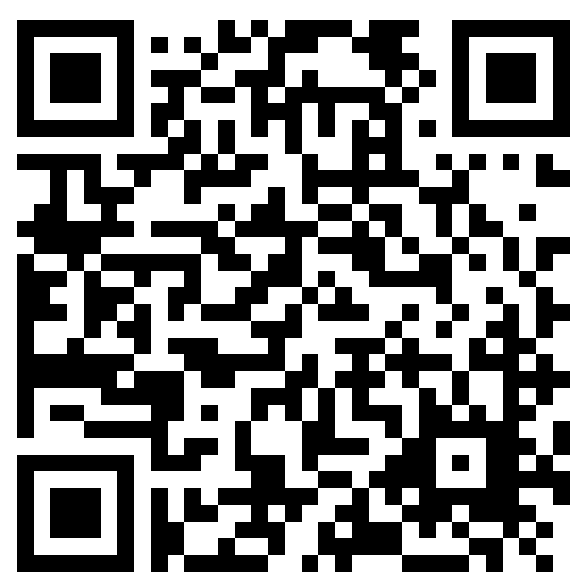

